Vol. 4, No. 1, 2021

\author{
M. A. Sozanskyi, P. Yo. Shapoval, V. E. Stadnik, R. R. Guminilovych, O. P. Kurylo \\ Lviv Polytechnic National University, \\ Department of Physical, Analytical and General Chemistry \\ martyn.a.sozanskyi@lpnu.com
}

\title{
QUANTUM-CHEMICAL MODELING OF THE PROCESSES OF CADMIUM SULFIDE AND CADMIUM SELENIDE FILMS SYNTHESIS IN AQUEOUS SOLUTIONS
}

https://doi.org/ 10.23939/ctas2021.01.026

The quantum-chemical modeling of the synthesis process chemistry of CdS and CdSe in aqueos solutions was carried out. For that reason, the $\mathrm{CdS}$ synthesis simulation was carried out through the formation of $\mathrm{Cd}(\mathrm{II})$ complex forms with the trisodium citrate and ammonium hydroxide. At the CdSe synthesis, the sodium selenosulfate with and without trisodium citrate was used. It was established that this process passes through several intermediate stages with the transitional reactive complexes formation. On the basis of obtained data, the energy stages diagrams are constructed and the comparison of $\mathrm{CdS}$ and CdSe synthesis processes with various complexing agents has been carried out. The CdS and CdSe films were obtained by chemical synthesis method from an aqueous solution of cadmium salt, complexing and chalcogenizing agents. X-ray phase analysis confirmed the formation of desired compounds, which was predicted by modeling.

Key words: cadmium sulfide; cadmium selenide; thin films; quantum-chemical modeling; semiempirical methods; semiconductors.

\section{Introduction}

The semi-empirical method of quantum chemistry is one of the methods that can be used to model possible ways of chemical reactions [1-3]. The main theory about metal chalcogenide films formation from aqueous solution were described in Refs. [4-6]. According to it, the main factors affecting the course of the reaction, is: concentration of initial reagents of the solution, the physical parameters of the process (temperature, synthesis duration, etc.); nature of complexing and chalcogenizing agents that surround the metal ion and generate chalcogen ions during the synthesis, respectively; nature of the substrate surface on which the films are formed.

According to Ref. [4], the formation of transitional molecular reactive complexes (TMRC), associates, cluster and colloidal forms were possible during the synthesis process in the working solution. It's due to cooperation and fluctuation phenomena, which occur between the liquid and solid phases (newly formed the reaction product and substrate) at a short distance from the latter.

Some metals ions $\left(\mathrm{M}=\mathrm{Pb}^{2+}, \mathrm{Cu}^{2+}, \mathrm{Cd}^{2+}, \mathrm{Hg}^{2+}\right)$, can form complexes with thiourea of $\left[\mathrm{Me}\left(\left(\mathrm{NH}_{2}\right)_{2} \mathrm{CS}\right)_{4}\right]^{2+}$ type $[4,7]$. From the reference data $[4,8]$, the value of the stability constant of such cadmium complex is smaller than with used in this work complexing agents (trisodium citrate and ammonia hydroxide) in order to deposit cadmium sulfide. So, initially it will be complex formation with that used complexing agents.

The information about comlpex formation or stability constants of cadmium with sodium selenosulfate $\left(\mathrm{Na}_{2} \mathrm{SeSO}_{3}\right)$ is not found in literature data. So it is logical to assume the $\mathrm{Cd}(\mathrm{OH})_{2}$ formation, at least initially, after adding sodium selenosulfate to the cadmium salt. That's because $\mathrm{Na}_{2} \mathrm{SeSO}_{3}-$ is the salt of weak acid. Another case when some compexing agent is present in the working solution like trisodium citrate. Then it will be the complex formation with that agent. 
In continuation about TMRC, during cadmium chalcogenides synthesis, there will be formation of intermediate complexes of $\left[\mathrm{L}_{\mathrm{n}} \cdots \mathrm{Cd} \cdots\left(\mathrm{NH}_{2}\right)_{2} \mathrm{CS}\right]$ or $\left[\mathrm{L}_{\mathrm{n}} \cdots \mathrm{Cd} \cdots \mathrm{SeSO}_{3}\right]$ type, where cadmium is coordinated on the one hand by ligands of the complexing agent or hydroxide groups, and on the other by thiourea or selenosulfate. The decomposition process of such intermediate complexes, as a rule, involves the formation of molecular forms, and then monomolecular layers of cadmium chalcogenide. To reduce the amount formation of by-products, it is necessary to create conditions in which the supply of cadmiumand chalcogen-containing agents will be the same.

\section{Aim of the work}

Implementation of quantum-chemical modeling of the CdS and CdSe synthesis processes with the use of PM6 or PM7 method in MOPAC 2016 software package on the basis of the hypothesis about the possibility of formation of transient reactive complexes, associates, clusters, structures of colloidal nature, which are structural units during the synthesis of cadmium chalcogenide films due to the effects of co-operation and fluctuation in the working solution. Comparison of the obtained results of CdS and CdSe simulations with the investigated properties of respective films. Feasibility and efficiency evaluation of the synthesis in observed systems.

\section{Materials and research methods}

Modeling and calculations of the system energy change $(\Delta \mathrm{E})$ for the synthesis stages of cadmium sulfide were carried out by the semiempirical PM7 method [9] and cadmium selenide by the PM6 method [10] with the use of MOPAC 2016 software package [11] and the Winmostar graphical interface [12].

The synthesis of CdS films was carried out from a working solution prepared by mixing aqueous solutions of cadmium chloride $\left(\mathrm{CdCl}_{2}\right)$, complexing agent, thiourea $\left(\left(\mathrm{NH}_{2}\right)_{2} \mathrm{CS}\right)$ and, if necessary, the $\mathrm{pH}$ regulator. Solutions of trisodium citrate $\left(\mathrm{Na}_{3} \mathrm{C}_{6} \mathrm{H}_{5} \mathrm{O}_{7}\right)$ or ammonium hydroxide $\left(\mathrm{NH}_{4} \mathrm{OH}\right)$ were used as complexing agents. The exact synthesis parameters of CdS films are given in Refs. [13, 14].

The synthesis of CdSe films was carried out from a working solution prepared by mixing aqueous solutions of cadmium chloride $\left(\mathrm{CdCl}_{2}\right)$, sodium selenosulfate $\left(\mathrm{Na}_{2} \mathrm{SeSO}_{3}\right)$ and trisodium citrate $\left(\mathrm{Na}_{3} \mathrm{C}_{6} \mathrm{H}_{5} \mathrm{O}_{7}\right)$ or without it. The exact synthesis parameters of CdSe films are given in Refs. [15, 16].

The X-ray diffraction patterns of deposited $\mathrm{CdS}$ and CdSe films samples were performed with the use of DRON-3.0 diffractometer ( $\mathrm{Cu} \mathrm{K \alpha ^{- }}$ radiation). The primary treatment of films diffractogram for the identification of phases was carried out by using PowderCell program [17].

\section{Results and discussion}

The results of quantum chemical modeling of the CdS and CdSe films synthesis chemistry in aqueous solutions with various complexing agents by semi-empirical methods are presented in Table. The geometry of starting cadmium complexes are illustrated on Fig. 3-5.

Quantum-chemical modeling of CdS synthesis chemistry with $\mathrm{Na}_{3} \mathrm{C}_{6} \mathrm{H}_{5} \mathrm{O}_{7}$ [13].

Initially, when mixing solutions of cadmium salt and trisodium citrate, a soluble $\left[\mathrm{Cd}\left(\mathrm{C}_{6} \mathrm{H}_{5} \mathrm{O}_{7}\right)\right]^{-}$ complex is formed (Fig. 1), where citrate ion plays the role of a ligand.

As can be seen from the conducted quantumchemical modeling (Table, no. 1, stages 1-2, 2-3) that after adding thiourea and a small amount of $\mathrm{pH}$ regulator to the solution, the $\left[\left(\mathrm{NH}_{2}\right)_{2} \mathrm{CS} \cdots \mathrm{Cd}(\mathrm{OH})_{2}\left(\mathrm{C}_{6} \mathrm{H}_{5} \mathrm{O}_{7}\right)\right]^{3-}$ TMRC is formed in the early stages of deposition. In this TMRC the Cd atom is coordinated with the $\mathrm{S}$ atom of thiourea (Fig. 3). This process is accompanied by reduction of the system energy $(\Delta \mathrm{E})$, that is, the process is energetically efficient.

At the next stages 3-5, transition states occur when the hydrogen atoms of $\left(\mathrm{NH}_{2}\right)_{2} \mathrm{CS}$ rearrange with two hydroxyl groups. As a result, two water molecules are detached from the $\left[\left(\mathrm{NH}_{2}\right)_{2} \mathrm{CS} \cdots \mathrm{Cd}(\mathrm{OH})_{2}\left(\mathrm{C}_{6} \mathrm{H}_{5} \mathrm{O}_{7}\right)\right]^{3-}$ TMRC with the appearance of a new $\left[\left(\mathrm{N}_{2} \mathrm{H}_{2} \mathrm{CS} \cdots \mathrm{Cd}\left(\mathrm{C}_{6} \mathrm{H}_{5} \mathrm{O}_{7}\right)\right]^{3-}\right.$ TMRC. The result of these stages is slight changes in total energy of the system.

At the last stages 5-6, which is the most energy consuming, the newly formed intermediate complex decomposed with the formation of cadmium sulfide, citrate ion and cyanamide.

During deposition process, the citrate ion $\left(\mathrm{C}_{6} \mathrm{H}_{5} \mathrm{O}_{7}{ }^{3-}\right)$ does not change its structure and performs only a ligand role.

Quantum-chemical modeling of CdS synthesis chemistry with $\mathrm{NH}_{4} \mathrm{OH}$. 
M. A. Sozanskyi, P. Yo. Shapoval, V. E. Stadnik, R. R. Guminilovych, O. P. Kurylo

Cadmium can form with $\mathrm{NH}_{4} \mathrm{OH}$ complexing agent the water-soluble complexes of cadmium tetraammonia $\left[\mathrm{Cd}\left(\mathrm{NH}_{3}\right)_{4}\right]^{2+}$ and cadmium hexaammonia $\left[\mathrm{Cd}\left(\mathrm{NH}_{3}\right)_{6}\right]^{2+}$.

Modeled stages of CdS and CdSe films synthesis and energy stages diagrams

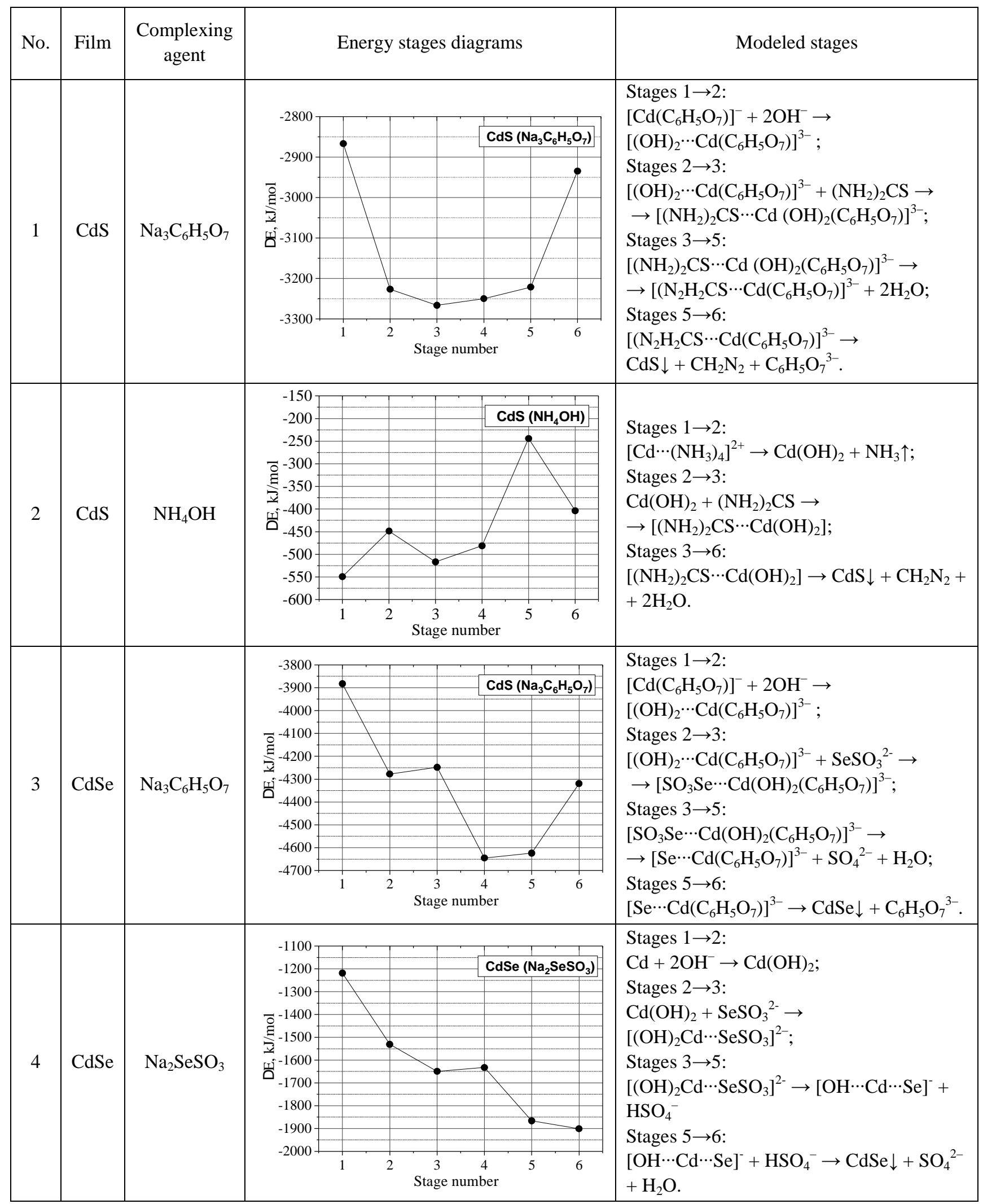




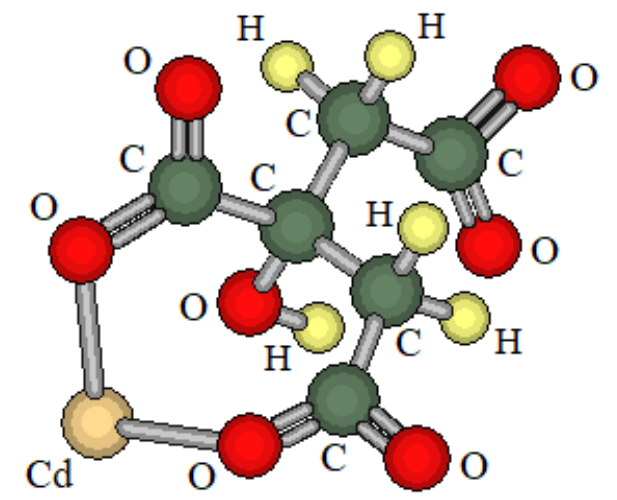

Fig. 1. The modeled $\left[\mathrm{Cd}\left(\mathrm{C}_{6} \mathrm{H}_{5} \mathrm{O}_{7}\right)\right]^{-}$complex

Since, according to reference data [8], the value of stability constant for the four-coordinated cadmium complex with ammonia $\left(\mathrm{pK}^{1-4}=6.56\right)$ is two orders higher than six-coordinated $\left(\mathrm{pK}^{1-6}=4.56\right)$, so the $\left[\mathrm{Cd}\left(\mathrm{NH}_{3}\right)_{4}\right]^{2+}$ complex form (Fig. 2) will be present in the working solution.

It can be seen from the modeling (Table, no. 3, stages 1-2) that CdS deposition is preceded by the stage of nucleation of the cadmium hydroxide $\left(\mathrm{Cd}(\mathrm{OH})_{2}\right)$ phase. That's because with increasing system energy, the complex $\left[\mathrm{Cd}\left(\mathrm{NH}_{3}\right)_{4}\right]^{2+}$ decomposes to $\mathrm{Cd}(\mathrm{OH})_{2}$ and the ammonia as volatile compound evaporates from the working solution. This reduces the $\mathrm{NH}_{4} \mathrm{OH}$ concentration during the process of $\mathrm{CdS}$ synthesis. As a consequence, the $\mathrm{pH}$ value decreases, which promotes the formation of cadmium hydroxide. In the subsequent stages, thiourea is combined with the newly formed $\mathrm{Cd}(\mathrm{OH})_{2}$ (stages 2-3). This produces the $\left[\left(\mathrm{NH}_{2}\right)_{2} \mathrm{CS} \cdots \mathrm{Cd}(\mathrm{OH})_{2}\right]$ TMRC (Fig. 4).

After that, during the further heating (stages 3-6), the intermediate complex undergoes to rearrangement of hydrogen atoms with detaching of water molecules and destruction into cyanamide molecules and insoluble cadmium sulfide. Going to the last stage leads to a decrease in the total energy of the system, however, in the process of passing through the stages 3-6 there are local minimum and maximum of $\Delta E$ energy change.

Quantum-chemical modeling of CdSe synthesis chemistry with $\mathrm{Na}_{3} \mathrm{C}_{6} \mathrm{H}_{5} \mathrm{O}_{7}$.

Similarly to the synthesis of CdS from a $\mathrm{Na}_{3} \mathrm{C}_{6} \mathrm{H}_{5} \mathrm{O}_{7}$ solution, in the case of CdSe formation from citrate system, a cadmium citrate $\left[\mathrm{Cd}\left(\mathrm{C}_{6} \mathrm{H}_{5} \mathrm{O}_{7}\right)\right]^{-}$ complex will form. Its geometry are illustrated on Fig. 1. As can be seen from the performed modeling

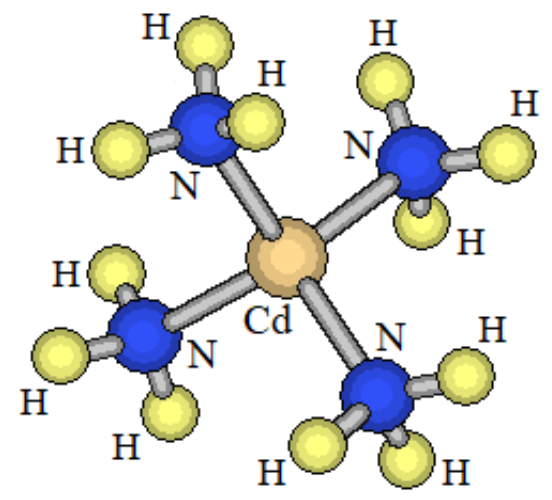

Fig. 2. The modeled $\left[\mathrm{Cd}\left(\mathrm{NH}_{3}\right)_{4}\right]^{2+}$ complex

(Table 1, no. 3, stages 1-2) the beginning of process will be also analogous to the corresponding case of CdS synthesis, where $\left[(\mathrm{OH})_{2} \cdots \mathrm{Cd}\left(\mathrm{C}_{6} \mathrm{H}_{5} \mathrm{O}_{7}\right)\right]^{3-}$ TMRC is formed.

Next, there will be the difference in further process be due to the other nature of the chalcogenizing reagent, namely the sodium selenosulfate. Thus, at stages $2-3$, the new $\left[\mathrm{SO}_{3} \mathrm{Se} \cdots \mathrm{Cd}(\mathrm{OH})_{2}\left(\mathrm{C}_{6} \mathrm{H}_{5} \mathrm{O}_{7}\right)\right]^{3-}$ TMRC appears. During the stages 3-5, the group $\left(-\mathrm{SO}_{3}\right)$ interacts with the $\mathrm{OH}^{-}$groups to form the $\mathrm{SO}_{4}{ }^{2-}$ ion and water. At the end of the process (stages 5-6) the final product is formed - cadmium selenide and citrate ion. The last stages occurs only if energy is provided to the system. Other stages occur either with the release of energy or with the provision of a small amount of it to the system.

Quantum-chemical modeling of CdS synthesis chemistry with $\mathrm{Na}_{2} \mathrm{SeSO}_{3}$.

In the case of mixing of a cadmium salt solution only with sodium selenosulfate solution, the $\mathrm{Cd}(\mathrm{OH})_{2}$ is formed at the beginning of deposition (Table, no. 4, stages 1-2). As mentioned earlier, that's because under normal conditions a solution of sodium selenosulfate as a salt of a weak acid has an alkaline medium.

At stages 2-3, the newly formed $\mathrm{Cd}(\mathrm{OH})_{2}$ approaches the selenosulfate ion and forming the $\left[(\mathrm{OH})_{2} \mathrm{Cd} \cdots \mathrm{SeSO}_{3}\right]^{2-}$ TMRC (Fig. 6).

Next, the $-\mathrm{SO}_{3}$ group of the intermediate complex rotates in the direction of one of the $\mathrm{OH}^{-}$ groups, interacts with it to form the $\left[\mathrm{OH}^{\cdots} \mathrm{Cd} \cdot{ }^{\cdots} \mathrm{Se}\right]^{-}$ TMRC and detach of $\mathrm{HSO}_{4}^{-}$ion (stages 3-4). Finally, at the last stages $5-6$, the $\left[\mathrm{OH}^{\cdots} \mathrm{Cd} \cdots \mathrm{Se}\right]^{-}$ decomposes with the formation of final product CdSe. 


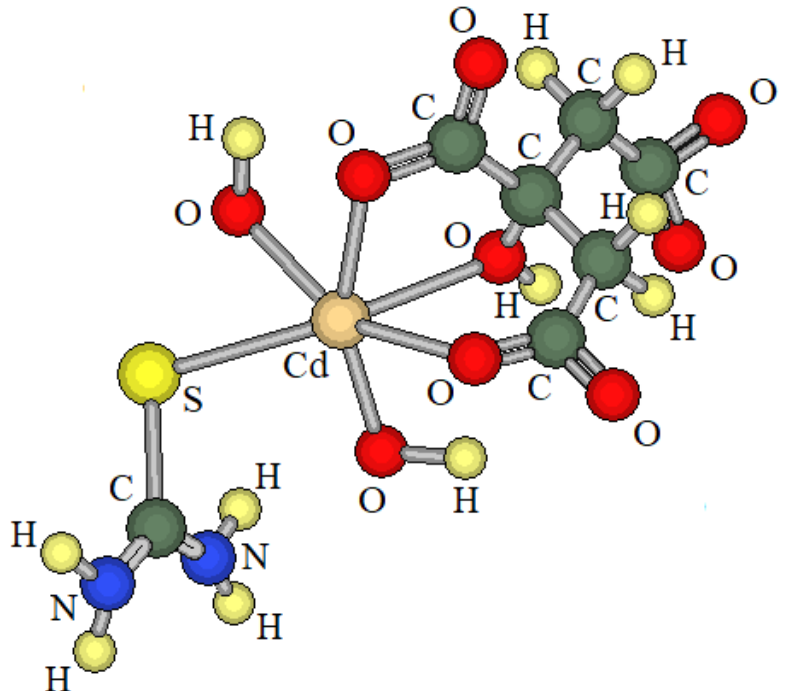

Fig. 3. The modeled $\left[\left(\mathrm{NH}_{2}\right)_{2} \mathrm{CS} \cdots \mathrm{Cd}(\mathrm{OH})_{2}\left(\mathrm{C}_{6} \mathrm{H}_{5} \mathrm{O}_{7}\right)\right]^{3-}$ TMRC

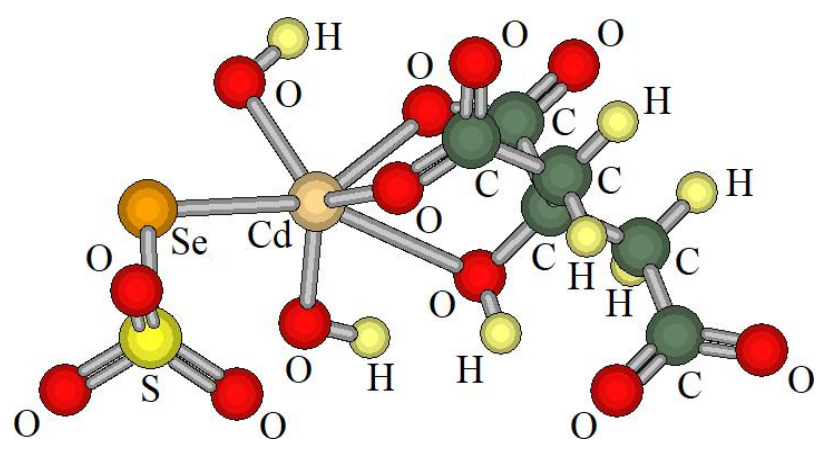

Fig. 5. The modeled $\left[\mathrm{SO}_{3} \mathrm{Se} \cdots \mathrm{Cd}(\mathrm{OH})_{2}\left(\mathrm{C}_{6} \mathrm{H}_{5} \mathrm{O}_{7}\right)\right]^{3-}$ TMRC

During all stages, the total energy of the system $\Delta \mathrm{E}$ decreases, only stage 4 requires a small supply of energy. This indicates that in this system there should be a significant reaction rate of the $\mathrm{CdSe}$ formation. So, it is necessary to create conditions for the most efficient conversion of reagents. This will be in order to deposit the resulting product in the film form on the substrate surface as much as possible. Also, at the same time, to not precipitate much of CdSe in the volume of working solution.

To verify the results of quantum-chemical modeling of CdS and CdSe obtaining, the CdS and CdSe films were synthesized experimentally under modeled conditions. Their X-ray phase analysis was performed (Figs. 7, 8). It has been established that $\mathrm{CdS}$ coatings contained two phases - CdS of cubic (sphalerite-type) modification and hexagonal

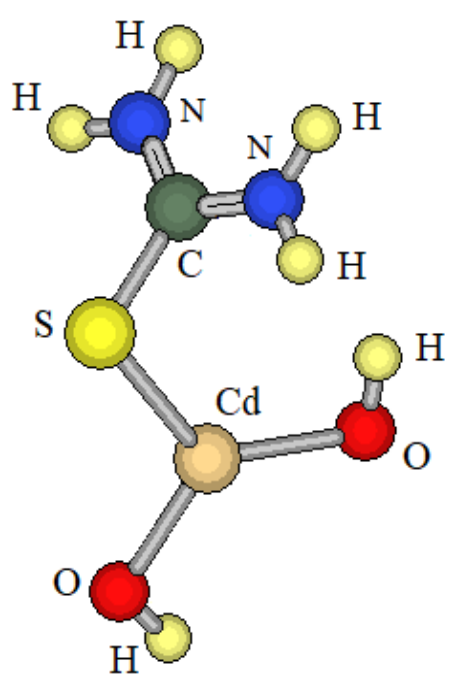

Fig. 4. The modeled $\left[\left(\mathrm{NH}_{2}\right)_{2} \mathrm{CS} \cdots \mathrm{Cd}(\mathrm{OH})_{4}\right]^{2-} \mathrm{TMRC}$

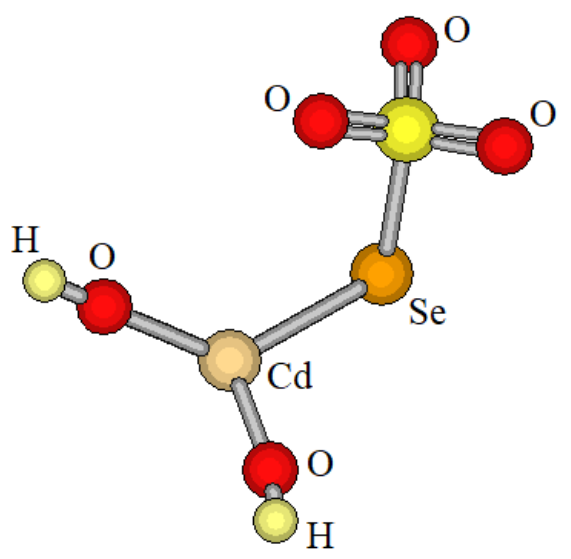

Fig. 6. The modeled $\left[\mathrm{SO}_{3} \mathrm{Se} \cdots \mathrm{Cd}(\mathrm{OH})_{2}\right]^{4-} \mathrm{TMRC}$

(wurtzite-type) modification. The CdSe coatings contain the corresponding phase of cubic (sphalerite-type) modification olny. The formation of corresponding was predicted by quantum-chemical modeling.

According to the studies described in [13, 14], it was established that at $\mathrm{Na}_{3} \mathrm{C}_{6} \mathrm{H}_{5} \mathrm{O}_{7}$ and $\mathrm{NH}_{4} \mathrm{OH}$ usage during $\mathrm{CdS}$ films synthesis, the surface of obtained coatings were solid, smooth and have a mirror hue. The deposition duration of the case of ammonia hydroxide use is shorter than at the use of trisodium citrate, probably due to ammonia evaporation as volatile compound from the working solution. This promotes the $\mathrm{Cd}(\mathrm{OH})_{2}$ nucleation for its further tranforming into the TMRC. As result, the passage of the first three stages probably goes easier.

The CdSe films synthesis with the use of $\mathrm{Na}_{2} \mathrm{SeSO}_{3}$ without $\mathrm{Na}_{3} \mathrm{C}_{6} \mathrm{H}_{5} \mathrm{O}_{7}$ is less long than with it $[15,16]$. The obtaining coating were solid, smooth 
and have a mirror hue. However, the trisodium citrate usage leads to getting greater CdSe films thickness. But deposited in that case coatings is less adhesive to the glass substrates than when $\mathrm{Na}_{3} \mathrm{C}_{6} \mathrm{H}_{5} \mathrm{O}_{7}$ is not in use. This can be solved by adding sulfur-containing chalcogenizer to obtain of cadmium sulfide-selenide $\left(\mathrm{CdS}_{\mathrm{x}} \mathrm{Se}_{1-\mathrm{x}}\right)$ films of substitutional solid solution [18].

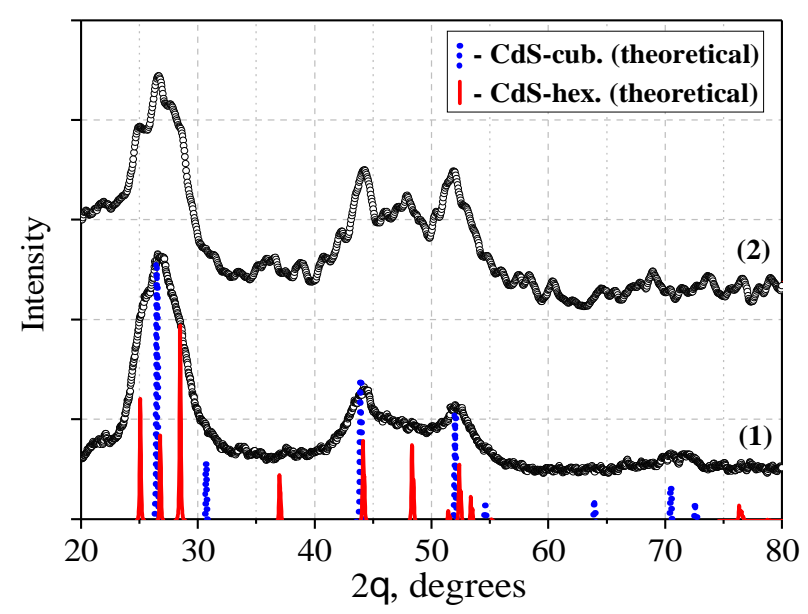

Fig. 7. The XRD patterns of CdS films, obtained with the use of $\mathrm{Na}_{3} \mathrm{C}_{6} \mathrm{H}_{5} \mathrm{O}_{7}(1) ; \mathrm{NH}_{4} \mathrm{OH}(2)$ and the theoretical diffraction patterns of $\mathrm{CdS}$

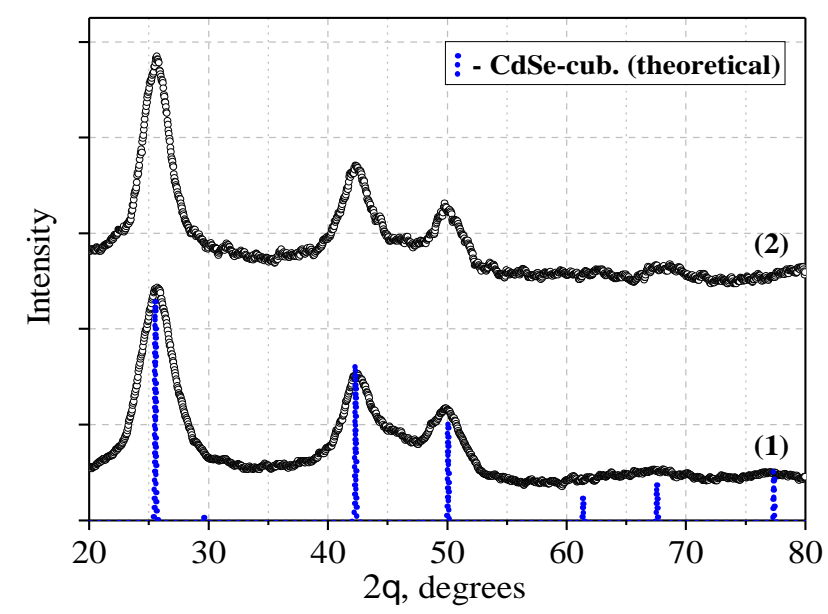

Fig. 8. The XRD pattern of CdSe films, obtained with the use of $\mathrm{Na}_{3} \mathrm{C}_{6} \mathrm{H}_{5} \mathrm{O}_{7}$ and $\mathrm{Na}_{2} \mathrm{SeSO}_{3}$ (1); only $\mathrm{Na}_{2} \mathrm{SeSO}_{3}$ (2) and the theoretical diffraction pattern of CdSe

\section{Conclusions}

On the basis of the performed work, the following summation were made:

The main factors that influencing on the metal sulfides films formation during their chemical synthesis from aqueous solution were described.

For the first time a quantum-chemical modeling of synthesis chemistry of $\mathrm{CdS}$ films with the use of $\mathrm{Na}_{3} \mathrm{C}_{6} \mathrm{H}_{5} \mathrm{O}_{7}$ or $\mathrm{NH}_{4} \mathrm{OH}$ complexing agents and $\mathrm{CdSe}$ films with the use of $\mathrm{Na}_{2} \mathrm{SeSO}_{3}$ with $\mathrm{Na}_{3} \mathrm{C}_{6} \mathrm{H}_{5} \mathrm{O}_{7}$ or only $\mathrm{Na}_{2} \mathrm{SeSO}_{3}$ was carried out on the basis of the proposed hypothesis. It was established that synthesis process passes through several intermediate stages with the transitional reactive complexes formation. On the basis of obtained data, the energy stages diagrams were constructed.

From the performed simulations and calculations for the two cases of cadmium sulfide formation, the $\mathrm{Na}_{3} \mathrm{C}_{6} \mathrm{H}_{5} \mathrm{O}_{7}$ complexing agent behaves energetically more profitably than the $\mathrm{NH}_{4} \mathrm{OH}$ during the $\mathrm{CdS}$ synthesis in the aggregate of all stages of synthesis reactions. In the case of cadmium selenide formation, the synthesis with the use of $\mathrm{Na}_{2} \mathrm{SeSO}_{3}$ only without $\mathrm{Na}_{3} \mathrm{C}_{6} \mathrm{H}_{5} \mathrm{O}_{7}$ is energetically more profitable.

The synthesis of CdS and CdSe films was performed under modeled conditions. The X-ray phase analysis confirmed the $\mathrm{CdS}$ and $\mathrm{CdSe}$ compounds formation using the corresponding reagents mentioned above.

The comparison of the features chemical synthesis and obtained $\mathrm{CdS}$ and CdSe films in the studied systems is carried out. The obtained results can be useful for planning the synthesis of cadmium sulfide and cadmium selenide films from aqueous solution and with the necessary properties for their further use in electronics.

\section{References}

1. Thiel, W. (2014). Semiempirical quantum-chemical methods. WIREs Computational Molecular Science, 4(2), 145-157. doi:10.1002/wcms.1161

2. Bertoli, A. C., Carvalho, R., Freitas, M. P., Ramalho, T. C., Mancini, D. T., Oliveira, M. C., Varennes A., \& Dias, A. (2015). Theoretical and experimental investigation of complex structures citrate of zinc (II). Inorganica Chimica Acta, 425, 164-168. doi: 10.1016/j.ica.2014. 10.025

3. Bertoli, A. C., Carvalho, R., Freitas, M. P., Ramalho, T. C., Mancini, D. T., Oliveira, M. C., Varennes A., \& Dias, A. (2015). Theoretical spectroscopic studies and identification of metal-citrate $(\mathrm{Cd}$ and $\mathrm{Pb})$ complexes by ESI-MS in aqueous solution. Spectrochimica Acta Part A: Molecular and Biomolecular Spectroscopy, 137, 271-280. doi: 10.1016/j.saa.2014.08.053

4. Markov, V., Maskayeva, L., \& Ivanov, P. (2006). Gidrokhimicheskoye osazhdeniye plenok sul'fidov metallov: modelirovaniye i yeksperiment. Yekaterinburg: UrO RAN

5. Berg, L., Meshchenko, K., \& Bogomolov, Yu. (1970). Vybor optimal'nykh usloviy osazhdeniya plenok 


\section{A. Sozanskyi, P. Yo. Shapoval, V. E. Stadnik, R. R. Guminilovych, O. P. Kurylo}

sul'fida svintsa. Neorganicheskiye materialy, 6(7), 13371338.

6. Markov, V, \& Maskayeva, L. (2005). Raschet usloviy obrazovaniya tverdoy fazy khal'kogenidov metallov pri gidrokhimicheskom osazhdenii. Yekaterinburg: GOU VPO UGTU-UPI.

7. Jalilehvand, F., Amini, Z., \& Parmar, K. (2012). Cadmium (II) Complex Formation with Selenourea and Thiourea in Solution: An XAS and 113Cd NMR Study. Inorganic Chemistry, 51(20), 10619-10630. doi:10.1021/ic300852t

8. Лурьє, Ю. Ю. (1989). Справочник по аналитической химии. Москва: Химия.

9. Bochkarev, V., Soroka, L., Klimova, T., \& Velikorechina, L. (2015). Modeling of Condensation Reaction of Aniline to Diphenylamine by PM7 Method. Procedia Chemistry, 15, 320-325. doi:10.1016/j.proche. 2015.10.051

10. Somekawa, K. (2014). Molecular Simulation of Potential Energies, Steric Changes and Substituent Effects in Photochromic Cyclization/Cycloreversion of Three Kinds of Dithienylethenes by MOPAC-PM6 Method. Journal of Computer Chemistry, Japan, 13(4), 233-241. doi:10.2477/jccj.2014-0013

11. Stewart, J. (2016). MOPAC2016 Home Page. Retrieved from http://openmopac.net/MOPAC2016.html

12. Senda, N. (2018). Winmostar - Structure modeler and visualizer for free Chemistry simulations. Retrieved from https://winmostar.com/

13. Sozanskyi, M. A., Shapoval, P. Y., Guminilovych, R. R., Laruk, M. M., \& Yatchyshyn, Y. Y. (2019). Synthesis of cadmium sulfide thin films from an aqueous solution containing sodium citrate. Voprosy
Khimii I Khimicheskoi Tekhnologii, (2), 39-46. doi:10.32434/ 0321-4095-2019-123-2-39-46

14. Il'Chuk, G. A., Kurilo, I. V., Kus'Nezh, V. V., Petrus', R. Y., \& Shapoval, P. I., Guminilovich, R. R., Partyka, M.V., Tokarev, S. V. (2014). Growth of thin CdS films on glass substrates via reaction of thiourea with cadmium acetate in aqueous solution. Inorganic Materials, 50(8), 762767. doi:10.1134/s0020168514080093.

15. Sozanskyi, M., Shapoval, P., Guminilovych, R., Yatchyshyn, Y., Stadnik, V., \& Koval, N. (2018). Khimichne osadzhennya $z$ vann plivok kadmiy sul'fidu ta kadmiy selenidu. Proceedings of the XVI International Scientific and Methodical Conference SHLA-2018, April 25-27, 2018. Lviv, Ukraine, 173-174.

16. Guminilovych, R. R., Shapoval, P. I., Yatchyshyn, I. I., Il'Chuk, G. A., \& Kusnezh, V. V. (2013). Chemical surface deposition and growth rate of thin CdSe films. Russian Journal of Applied Chemistry, 86(5), 696-702. doi:10.1134/s1070427213050157

17. Kraus, W., \& Nolze, G. (1996). POWDER CELL a program for the representation and manipulation of crystal structures and calculation of the resulting X-ray powder patterns. Journal of Applied Crystallography, 29(3), 301-303. doi:10.1107/s0021889895014920

18. Sozanskyi, M. A., Guminilovych, R. R., Shapoval, P. Yo., Yatchyshyn, Yo. Yo., Stadnik, V., \& Koval, N. (2018). Methods of synthesis of CdSe films with good adhesion to glass substrates. Abstracts of the 5th International Congress "Sustainable Development: Environmental Protection. Energy Saving. Sustainable Environmental Management”, 26-29th September, 2018. Lviv, Ukraine, 91.

М. А. Созанський, П. Й. Шаповал, В. С. Стаднік, Р. Р. Гумінілович, О. П. Курило

Національний університет “Львівська політехніка”, кафедра фізичної, аналітичної та загальної хімії

\section{КВАНТОВО-ХІМІЧНЕ МОДЕЛЮВАННЯ ПРОЦЕСІВ СИНТЕЗУ ПЛІВОК КАДМІЙ СУЛЬФІДУ ТА КАДМІЙ СЕЛЕНІДУ У ВОДНИХ РОЗЧИНАХ}

Здійснено квантово-хімічне моделювання хімізму процесу синтезу $\mathrm{CdS}$ та $\mathrm{CdSe}$ у водних розчинах. Змодельовано синтез $\mathrm{CdS}$ із утворенням проміжних комплексних форм Cd(II) із тринатрій цитратом та амоній гідроксидом. Для синтезу CdSe використано натрію селеносульфат із тринатрій цитратом і без нього. Встановлено, що цей процес проходить через декілька проміжних стадій із утворенням перехідних реакційноздатних комплексів. На основі отриманих даних побудовано енергетичні діаграми стадій та здійснено порівняння процесів синтезу CdS i CdSe iз різними комплексоутворювальними реагентами. Методом хімічного синтезу отримано плівки CdS тa CdSe 3 водного розчину солі кадмію, комплексоутворюючого та халькогенізуючого реагентів. Рентгенофазовим аналізом підтверджено утворення цільових сполук, що було передбачено моделюванням.

Ключові слова: кадмій сульфід; кадмій селенід; тонкі плівки; квантово-хімічне моделювання; напівемпіричні методи; напівпровідники. 